A. S. Kucher,

Senior Lecturer;

ORCID: 0000-0001-5478-9463

A. V. Paulava,

$\mathrm{PhD}$ of Technical Sciences, Associate Professor,

ORCID: 0000-0003-3216-9989

Yanka Kupala State University of Grodno

Grodno, Belarus

\title{
DEVELOPMENT OF A COLLECTION OF TECHNOLOGICAL CARDS DISHES OF MODERN CUISINE
}

The article is devoted to the development of the collection, containing a universal collection of technological cards modern dishes of Belarusian cuisine. The need for this product is substantiated; the shortcomings of existing collections of recipes and technological cards for the production of culinary products are described. The main sections, the advantages of the developed resource are described; the target audience of consumers is indicated.

Keywords: technological cards, modern kitchen, dishes, public catering.

Relevance of the research topic. Current trends in the technology of cooking dishes involve the use of collections of recipes, which take into account the main features of cooking technologies using modern kitchen equipment, consumption rates of products and their physicochemical parameters.

Most modern officially published collections of recipes are simply a revision of previously existing collections. The compilers of the so-called new collections are not at all puzzled by the development of new recipes for dishes, the manufacture of which could use products not only of Soviet times. For example, in collections of recipes there are no dishes in the manufacture of which you can use kiwi, avocado, dorado or fennel. And the way out of this situation is to create a fundamentally new, modern collection of recipes.

Formulation of the problem. New technologies for the production of culinary products and non-traditional types of raw materials are rapidly entering the work of public catering facilities. At the same time, high competition, the constant growth of expectations of a modern guest of public catering facilities requires a special highlight from the enterprises. One of the most effective ways to attract guests is to develop branded (new) products.

The collection of technological cards dishes of modern cuisine are developed in order to best meet the demand of consumers of catering establishments. Dishes in the collection have innovative cooking technologies, high taste, original design, as well as an unusual flavor combination of products.

Analysis of recent research and publications. In Belarus the basic normative documents regulating the production of products of public catering are:

- A collection of recipes for dishes and culinary products for public catering enterprises, regardless of departmental affiliation and forms of ownership, approved by order of the Ministry of Trade of the Republic of Belarus dated November 9, 1995 No. 70. 
- The collection of technological cards for culinary products of public catering, approved by resolution No. 4 of the Ministry of Trade of the Republic of Belarus on February 25, 2014.

- The collection of technological cards of Belarusian dishes, approved by the Decree of the Ministry of Trade of the Republic of Belarus dated January 3, 2012 No. 2.

- The collection of technological cards of dietetic food, approved by the Decree of the Ministry of Trade of the Republic of Belarus and the Ministry of Health of the Republic of Belarus of February 12, 2003 No. 7/8.

- The collection of technological cards of dishes for students in institutions providing general secondary and vocational education, approved by the Decree of the Ministry of Trade of the Republic of Belarus dated July 11, 2006 No. 21.

-The collection of technological cards of confectionery and bakery products for commercial catering facilities, approved by the Decree of the Ministry of Trade of the Republic of Belarus dated April 20, 2007 No. 26.

In addition, public catering uses technological cards of production semi-finished products from meat, poultry, fish, sauces for trade organizations and public catering of all forms of ownership; a collection of technological standards for the nutrition of children and adolescents in health organizations; a collection of technological cards of modern dishes of world cuisine in 2 volumes.

Technological cardsof dishes, the recipe for preparation of which is contained in any of these collections, do not require additional approval. The recipes contain norms for the consumption of raw materials for the preparation of dishes; they establish uniform requirements for raw materials and finished products, process description of production dishes, their quality indicators, and rules for decorating dishes. However, the main drawback of the current documents is that raw material consumption norms are calculated on standard raw materials of certain conditions (categories). When using unconventional raw materials and semi-finished products that differ from those provided in the collections, food facilities are forced to develop and approve technological cards. In addition, a significant part of the products presented in the collections does not correspond to the latest trends in the culinary art.

Presenting main material. A collection of technological cards of dishes of modern cuisine has been developed (Fig. 1). The collection contains color photographs of dishes, which are a valuable visual aid and demonstrate how the finished dish looks.

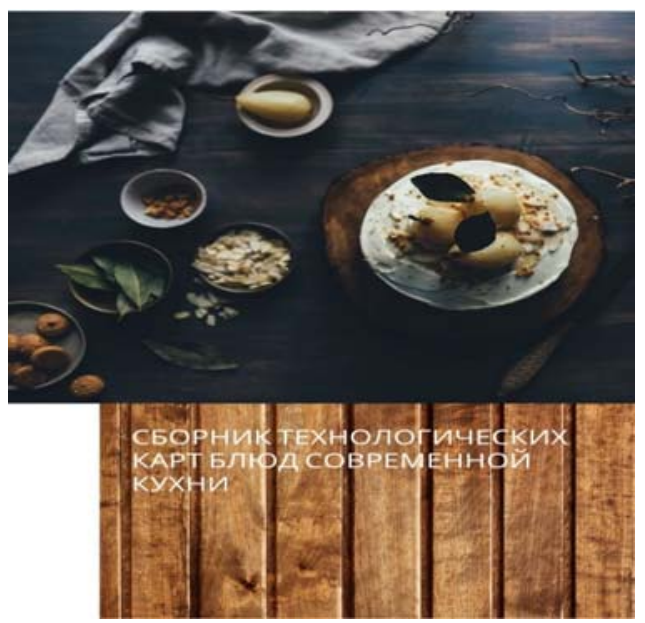

Figure 1. Appearance of the collection of technological cards of dishes of modern Belarusian cuisine 
The collection consists of 8 sections, including 123 recipes (Fig. 2):

1) Sandwiches («I want to be Italian» sandwich, Cheese-garlic sandwich, Vegetable sandwich, Warm sandwich with bacon and ham, etc.);

2) Cold Appetizers (Salmon in Swedish, Bruschetta with shrimp and curd cheese, Spinach Pkhali, etc. );

3) Sets (Wine Set, Beer Set, Cheese Fondue «Lumie», etc. );

4) Salads (Tuna Salad with fresh mushrooms, Pork Salad with sun-dried tomatoes, Status Salad, Provencal Salad, Honshu Salad in Japanese, Salad with orzo paste and Prosciutto ham, etc. );

5) Hot Snacks (Stock fish sticks, Skrembl et al. );

6) Soups (Onion Soup «Parmantier», Mashed Soup «Kurbis», Cream-soup of champignons, etc. );

7) Hot Dishes (Sous Vide hake on a broccoli pillow, Norwegian salmon with cream sauce, Dorado in salt carapace, Veal steak with vegetables, Pork loin papillot with prunes, Pork casserole with potatoes, Pork ribs with honey glaze, Chicken gratin in a pot, etc. );

8) Desserts (Chocolate Semifredo, Triffle, Tropical Iton Mess, Ginger Cake, etc.).

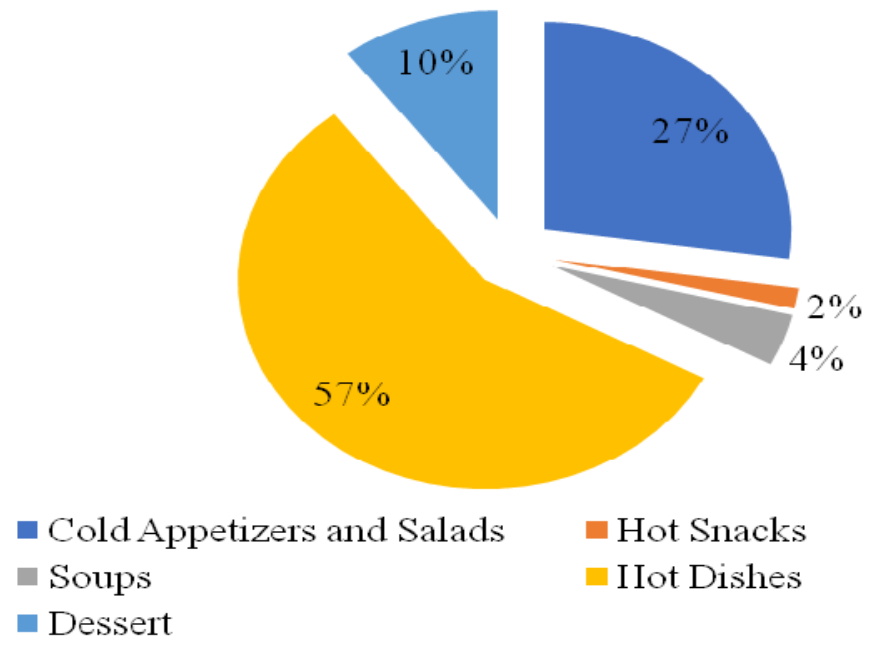

Figure 2. The percentage of culinary products in the collection

Dishes included in the collection are diverse in terms of the types of raw materials used, including non-traditional. All cooking technologies are based on modern trends in gastronomy: cooking in a combi oven, on the grill, WOK, Sous-Vide technology, sauté, papillot, glazing, various types of breading, confit, flambe, deglacing, gratin, etc. 
The developed collection will serve as a practical guide for specialists of all types of catering enterprises (managers, chefs, engineers-tecnologists, etc. ). The prepared recipes can be suitable not only for cafes, bars and restaurants, but also for a banquet menu, buffet tables of canteens.

Conclusions. As a result of the work done, a collection of technological cards of modern cuisine dishes was developed, which includes 8 sections and 123 technological maps for the production of culinary products.

The developed collection contains recipes for modern dishes prepared using non-traditional types of raw materials and new cooking methods. Technological cards included in the collection are compiled in accordance with the requirements of STB 1210-2010.

The developed collection is intended for employees of the public catering, lecturers and students of educational institutions of the corresponding profile.

\section{REFERENCES}

1. CHEFEXPERT-Pravil'nye dokumenty dlia obshchepita [CHEFEXPERT-The correct documents for catering]. (n. d. ) chefexpert. ru. Retrieved from https://www. chefexpert. ru/[inRussian].

2. Ministry of Trade of the Republic of Belarus. Collection of recipes for dishes and culinary products for public catering enterprises of all forms of ownership. Belarusian Culinary Association, 2012. 614p.

3. Radevich V. N., Vasilkova N. E. Directory of catering worker. LLC «Scientific Information Center-LHC», 2012. 426p.

4. Ministerstvo antimonopol'nogo regulirovaniia i torgovli Respubliki Belarus' [The Ministry of Antimonopoly Regulation and Trade of the Republic of Belarus]. (n. d. ) mart. gov. by. Retrieved from https://mart. gov. by/[in Russian]. 